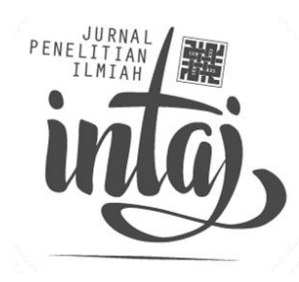

\title{
THE EFFECT OF METACOGNITIVE STRATEGY INSTRUCTION ON FIELD-INDEPENDENT AND FIELD-DEPENDENT EFL LEARNERS' WRITING SKILL
}

\author{
Muyassaroh (muyassaja@gmail.com) \\ Institut Agama Islam Al-Qolam Malang
}

(Received: Juni 2019 / Revised: Agustus 2019 / Accepted: September 2019)

\begin{abstract}
Penelitian ini bertujuan untuk mengkaji pengaruh pengajaran strategi belajar metakognitif terhadap kemampuan menulis mahasiswa Bahasa Inggris dengan gaya belajar bebas dan gaya belajar menggantung. Untuk itu rancangan penelitian yang digunakan dalam penelitian ini adalah kuasieksperimen. Sejumlah 25 mahasiswa (kelompok kendali) dan 22 mahasiswa (kelompok eksperimen) dipilih sebagai sampel. Intervensi yang diberikan pada kelompok eksperimen adalah pengajaran strategi belajar metakognitif. Berdasarkan kalkulasi statistik independent sample t-test, intervensi tersebut tidak mempengaruhi kemampuan menulis mahasiswa di kelompok eksperimen. baik mahasiswa dengan gaya belajar bebas maupun gaya belajar menggantung tidak memiliki perbedaan nilai rata-rata yang signifikan pada nilai test menulis mereka.
\end{abstract}

Keywords: Kemampuan menulis; Pengajaran strategi belajar metakognitif, Gaya belajar bebas dan gaya belajar menggantung.

\section{BACKGROUND}

Writing is considered the most complicated and challenging skill since it encompasses deriving and producing a unique verbal creation which is graphically docu- 
mented and it entails conscious effort and performance in compiling, developing, and analyzing ideas. ${ }^{1}$ Hence, mastering writing skills has been a difficult task for undergraduate students particularly in either second or foreign language perspectives. ${ }^{2}$ Learners face problems in organizing ideas, choosing suitable words or phrases, and presenting their ideas in a focused way when writing in second language. ${ }^{3}$ Learners require strategies to be capable of coping with these problems. ${ }^{4}$ An appropriate and effectual selection of learning strategies is fundamental for the success of language learning. ${ }^{5}$ Concerning this, language instructors are required to integrate language learning strategies into their teaching methods and approaches, scaffold the learners to employ the proper strategy for a particular goal or a specific proficiency, and persuade them to apply the strategies as regularly as possible. ${ }^{6}$ In short, learners require particular learning strategies to overcome their difficulties in writing performance.

Chamot defines learning strategies as the aware thinking and acts learners acquire in order to accomplish a learning target. ${ }^{7}$ Learning strategies also refer to particular manners of processing information which enhance understanding, learning, or retention of the information. ${ }^{8}$ O'Malley and Chamot (1985) believe that language learning strategies give so much contribution to successful language learning. ${ }^{9}$ Some studies on learning strategies belonging to Anderson (2003); Cohen (1998); Hosenfeld (1979); Macaro (2001); O’Malley and Chamot (1990); Oxford (2002);

M. Nosratinia \& S. Adibifar, "The Effect of Teaching Metacognitive Strategies on Fielddependent and Independent Learners' Writing", in Procedia-Social and Behavioral Sciences, 9(8), 2014, p. 1391.

Aliyu, "Developing Undergraduates' Awareness of Metacognitive Knowledge in Writing Through Problem-based Learning", in International Journal of Applied Linguistics \& English Literature, 5(7), 2016, p. 233.

Shabitha Mekala, \& Ponmani, "The Role of Metacognitive Strategies in Second Language Writing", in GSTF Journal on Education (JED), 4(1), 2016.

${ }^{4}$ Nasrin Khaki and Gholamreza Hessamy, "Metacognitive Strategies Employed by EFL Writers in Integrated and Independent Writing Tasks", in World Applied Sciences Journal, 22(11), 2013.

${ }^{5}$ T. Xia, "Application of Metacognitive Strategies in EFL Writing Instruction", in Advances in Social Science, Education and Humanities Research, 142, 2017.

${ }^{6}$ P. Zare, "Language Learning Strategies Among EFL/ESL Learners: A Review of Literature". In International Journal of Humanities and Social Science, 2(5), 2012.

A U Chamot, "Issues in Language Learning Strategy Research and Teaching", in Electronic Journal of Foreign Language Teaching, 1(1), 2004.

${ }^{8}$ P. Zare, "Language Learning Strategies....

9 J. Han, "A study on the influence of anxiety and metacognitive strategies on listening proficiency", in Journal of Chemical and Pharmaceutical Research, 6(6), 2014. 
Rubin (1975); Stern (1975); Wenden (2002) have underlined the significance of strategy instruction and its function to make learners more successful in scholastic career. ${ }^{10}$ It therefore can be inferred that learning strategies are beneficial for lessenning problems in language learning.

From the perspective of cognitive theory, O'Malley and Chamot (2001) categorize learning strategies into three main kinds, i.e. metacognitive strategies, cognitive strategies and social or affective strategies. ${ }^{11}$ Anderson (1991) argues that the most essential learning strategies among the others in improving learners' skill are metacognitive learning strategies. ${ }^{12}$ Some researches demonstrate that metacognitive learners who undertake conscious steps to understand what they are doing when they learn are potential to be the most successful learners. ${ }^{13}$ Through applying appropriate metacognitive strategies, learners are capable of overcoming problems in writing. ${ }^{14}$ Metacognitive strategies encourage learners to be self-reflective, conscious of argument and writing procedure, and inventive problem solvers since they methodically undertake the task of improving, writing, and revising an essay. ${ }^{15}$ Metacognitive strategy instruction stimulates the students' awareness about planning, monitoring and evaluating, thus aiding to build up self regulated learning, which results in progressive performance. ${ }^{16}$ Many researchers such as Ahmadi, Ketabi, and Rabiee, (2012); Sen (2009); Yuksel and Yuksel (2011) have discovered positive correlation between the use of metacognitive strategies and other skills, such as reading and writing. ${ }^{17}$ The aforementioned sentences can be concluded that metacognitive learning strategies are necessary to employ in order to improve writing performance.

10 S P. Nejad, "The effect of metacognitive strategy instruction on listening performance preintermediate iranian efl learners", in Indian Journal of Fundamental and Applied Life Sciences, 5(3), 2015.

${ }^{11}$ C. Yang., "A Study of Metacognitive Strategies Employed by English Listeners in an EFL Setting", in International Education Studies, 2(4), 2009, p.135

12 Nosratinia \& Adibifar, "The Effect of Teaching Metacognitive..., p. 1391.

${ }^{13}$ S P. Nejad, "The effect of metacognitive strategy .....

${ }^{14}$ Shabitha Mekala, \& Ponmani, "The Role of Metacognitive Strategies .....

15 J. Riddel, "Performance, Feedback, and Revision: Metacognitive Approaches to Undergraduate Essay Writing”, in Collected Essay on Learning and Teaching, 8, 2015, p. 79-96.

${ }^{16}$ P. Birjandi, "The Effect of Metacognitive Strategy Instruction on the Listening Performance of EFL Students", in International Journal of Linguistics, 4(2), 2012.

17 F. Zarrabi, "The Impact of Listening StrategyTraining on the Meta-Cognitive Listening Strategies Awareness of Different Learner Types", in English Language Teaching, 9(5), 2016. 
Etymologically metacognition refers to either thinking about thinking or cognition about cognition. ${ }^{18}$ Metacognitive strategies are information-processing theory which indicates an executive function and is employed by learners as the means to manage, monitor, and evaluate their learning activities. ${ }^{19}$ In terms of writing, metacognition deals with thinking of one's own writing consciousness of one's own writing processes. ${ }^{20} \mathrm{O}$ 'Malley and Chamot propose that metacognitive strategies compose of three stages: planning, monitoring, and evaluating. ${ }^{21}$ Planning assists learners in organizing the whole forthcoming processes and arises before engaging in a problem. ${ }^{22}$ Monitoring involves ensuring, validating, or correcting learners' understanding or work in the language task course. ${ }^{23}$ Evaluation refers to rechecking, keeping a learning plot, mirroring on what you did; assessing how well learners has carried out a learning task. ${ }^{24}$ The three stages of metacognitive strategies are comprehensive and appropriate to be implemented in learning context belonging to participants of this present study. Accordingly, this current study applies the aforementioned O'Malley and Chamot's taxonomy of metacognitive strategies. ${ }^{25}$

Learners' learning styles have an important role in the choice of language learning strategies. ${ }^{26}$ Learning styles refer to the beliefs, inclinations, and performances that people apply in order to learn in a particular condition..$^{27}$ According to Ellis, among a variety of learning styles, field-dependence and field independence have been considered to be potentially crucial in second language acquisition. ${ }^{28}$ Nozari \& Siamian convey in cognitive style, the field dependent learners are learners who are

18 X An \& Z Shi, "Does Metacognitive Instruction Improve Listening Comprehension?", in Theory and Practice in Language Studies, 3(4), 2013, p. 154

19 F LV \& H Chen, "A Study of Metacognitive-Strategies-Based Writing Instruction for Vocational College Students", in English Language Teaching, 3(3), 2010.

${ }^{20}$ Shabitha Mekala, \& Ponmani, "The Role of Metacognitive Strategies ....

${ }^{21} \mathrm{~T}$. Xia, "Application of Metacognitive Strategies...

22 M. Farahian, "Assessing EFL learners' writing metacognitive awareness", in Journal of Language and Linguistic Studies, 11(2), 2015.

${ }^{23} \mathrm{~T}$. Xia, "Application of Metacognitive Strategies ....

24 I Boghian, "Metacognitive Learning Strategies in Teaching English as a Foreign Language”, in Journal of Innovation in Psychology, Education and Didactics, 20(1), 2016.

${ }^{25}$ T. Xia, "Application of Metacognitive Strategies .....

${ }^{26}$ P. Zare, "Language Learning Strategies ....

27 Nozari, A Y \& Siamian, H. The Relationship between Field Dependent-Independent Cognitive Style and Understanding of English Text Reading and Academic Success. (Mater Sociomed, 2015).

28 W. Lu, "Metacognitive Reading Strategies of ESL Learners with Different Field Independent/Field Dependent Cognitive Styles. (Kuala Lumpur: Faculty of languages and linguistics university of Malaya, 2015). 
most impacted by their upbringing. ${ }^{29}$ The field independent learners recognize detached elements of the field, diverse from the organized conditions. ${ }^{30}$ If fielddependent learners tend to have free social arrangement, field independent learners incline to have inflexible social structure..$^{31}$ Field-independent learners are considered to be more likely to rely on internal indications and are capable of thinking analytically while field-dependent learners are inclined to focus on external cues and are more likely to be influenced by external atmosphere. ${ }^{32}$

Both learning styles and learning strategies influence learning outcomes since learners' selection on learning strategies is affected to a great level by the learning styles of the learners. ${ }^{33}$ Based on this notion, I can propose that students with learning styles of field-independence and field-dependence taught metacognitive learning strategies will have significant improvement in their writing performance. Accordingly, in this current study, I intend to examine whether metacognitive strategy instruction will enhance writing skill of learners with field-independent and field-dependent learning styles.

\section{METHOD}

Objective of this current study is to examine whether metacognitive strategy instruction enables to influence writing skill of field-dependent and fieldindependent learners. Accordingly, this present study is designed to employ a quasi-experimental research design especially posttest only design. Variables involved in this present study are writing skill (dependent variable), metacognitive strategy instruction (independent variable), and students with different learning styles (moderator variables). The moderator variable is Population included in this present study is 230 English Letter Department third semester students of State Islamic University of Malang who are fulfilling Essay Writing Course. Among the 230

${ }^{29}$ A Y Nozari \& H Siamian, "The Relationship between Field Dependent-Independent Cognitive Style and Understanding of English Text Reading and Academic Success", in Mater Sociomed, 27(1), 2015.

${ }^{30}$ S. Saadatmanesh, "Field Dependent/Independent Learning Strategies and the Knowledge of the Musical Notes", Journal of Science and Today's World, 2(9), 2013.

${ }^{31}$ M. Rezaee \& M. Farahian, "The Case Study of A Field-Independent English Language Learner, in Procedia-Social and Behavioral Sciences, 47, 2012.

${ }^{32}$ W. Lu, "Metacognitive Reading Strategies of ESL...

${ }^{33}$ Nosratinia \& Adibifar, "The Effect of Teaching Metacognitive.... 
students, 47 students are selected as the sample in which 22 students belong to experimental group and 25 students belong to control group. Sampling technique used is convenience sampling technique.

In order to achieve the data, first, prior to the treatment, the experimental group is required to fill Cognitive Figure Test (CSFT). Result of CSFT is employed to classify the subjects into either field-dependent learners or field-independent learners. CSFT is considered more effective than GEFT (Group Embedded Figures Test) since CSFT has been developed by Psychology Department of Beijing Normal University based on Witkin's GEFT. ${ }^{34}$ CSFT is a time-limited test and the time providing for finishing this test is just 10 minutes. ${ }^{35}$

Subsequently, the subjects in experimental group receive the treatment i.e. metacognitive strategy instruction for some meetings. Metacognitive strategies employed for this present study is adapted from O'Malley and Chamot which involve planning, monitoring, and evaluation. The three components are integrated with collaborative writing. ${ }^{36}$ Collaborative writing is to the process which provides participants the opportunity to explore, discuss, cooperate, and develop their writing process. At the same time, the subjects in control group are not taught about metacognitive strategy instruction. They only get writing instruction integrated with collaborative writing.

Thereafter, both the experimental group and the control group conduct a writing test. It is necessary to do in order to identify whether the experimental group's writing skill enhances after receiving metacognitive strategy instruction if compared to the control group. The writing skill to be tested is a cause and effect expository essay. The topic is either positive or negative effect of the use of WhatsApp for their life. The subjects must write 250 words. The time allotted for them to compose the essay is 90 minutes. To score the subjects' writing test, analytic scoring is employed. This scoring technique enables to portray the sketch of students' writing quality ${ }^{37}$ Form of analytic scales employed for this current study is adapted from Jacob et al's. Jacob et al's scoring profile is selected for this present study since

\footnotetext{
${ }^{34}$ W. Lu, "Metacognitive Reading Strategies of ESL...

35 ibid

${ }^{36}$ T. Xia, "Application of Metacognitive Strategies

${ }^{37} \mathrm{M}$ A. Latief, Research Methods on Language Learning An Intoduction. (Malang: UM Press,
} 2012) 
it provides training materials and trial compositions in order to facilitate the users to reasonably and rapidly learn to apply the scoring profile. ${ }^{38}$

The collected data -i.e. experimental and control group's writing scores -then are analyzed using several statistical calculations such as descriptive statistics, fulfillment of statistical assumptions, and hypothesis testing. Having analyzed descriptively, the data's fulfillment of statistical assumptions i.e. normality and homogeneity testing are required to compute. When the statistical assumptions are fulfilled, Independent Samples T-Test is applied to identify whether the experimental group achieve better score in writing essay than control group.

\section{RESULT AND DISCUSSION}

\subsection{Result}

Prior to analyzing the collected data using descriptive statistics, normality and homogeneity testing, and independent sample t-test, inter-rater reliability of the data are measured using Pearson Product Moment Correlation and coefficient alpha. Both of these statistical calculations are employed to ensure consistency of two raters in scoring the writing scores. The calculation on Pearson Product Moment Correlation demonstrates that the reliability coefficient is .590 , which means that high level of consistency between rater one and rater two exists (see Table 3 ). The computation on coefficient alpha also indicates that the reliability coefficient is .739 in which it means that both raters achieve high level of internal consistency (see Table 4). To sum up, both calculation on Pearson Product Moment Correlation and coefficient alpha confirm that rater one and rater two have consistency in scoring control group and experimental groups' writing test. 
Table 1: Pearson Product Moment Correlation

\begin{tabular}{|rl|r|r|}
\hline & & Rater 1 & Rater 2 \\
\hline Rater 1 & Pearson Correlation & 1 & $.590^{\prime \prime}$ \\
& Sig. (2-tailed) & & .000 \\
& $N$ & 47 & 47 \\
\hline Rater 2 & Pearson Correlation & $.590^{\prime \prime}$ & 1 \\
& Sig. (2-tailed) & .000 & \\
& $N$ & 47 & 47 \\
\hline \multicolumn{2}{|c|}{ *. Correlation is significant at the 0.01 level (2-tailed). }
\end{tabular}

Table 2: Coefficient Alpha

\begin{tabular}{|c|c|c|}
\hline $\begin{array}{c}\text { Cronbach's } \\
\text { Alpha }\end{array}$ & $\begin{array}{c}\text { Cronbach's } \\
\text { Alpha Based } \\
\text { on } \\
\text { Standardized } \\
\text { Items } \\
\end{array}$ & Nof ltems \\
\hline .739 & .742 & 2 \\
\hline
\end{tabular}

Characteristics of the data dealing with the variables under the investigation are identified using descriptive statistics. Table 5 shows that the lowest writing score got by subject in the experimental group is 49.50 while that got by subject in the control group is 50. 50. The highest writing score belonging to the experimental group is 71.50 while the highest writing score belonging to the control group is 85 . 50. Average writing score achieved by the experimental group is 60. 3409. The control group achieves average writing score 61. Mean difference between both groups is 0.6591 . This means that metacognitive strategy instruction might be unable to influence the students' writing skill. However, this interpretation is not enough to conclude before analyzing the data using inferential statistics.

Table 3: Descriptive Statistics on the Subjects' writing scores

\begin{tabular}{|l|r|r|r|c|c|r|r|}
\hline & \multicolumn{1}{|c|}{$N$} & Minimum & Maximum & Sum & Mean & Std. Deviation & Variance \\
\hline Experimental Group & 22 & 49.50 & 71.50 & 1327.50 & 60.3409 & 5.47589 & 29.985 \\
Control Group & 25 & 50.50 & 85.50 & 1525.00 & 61.0000 & 7.68386 & 59.042 \\
Valid N (listwise) & 22 & & & & & & \\
\hline
\end{tabular}

Before identifying hypothesis testing through Independent Sample T-Test, homogeneity and normality testing are carried out to see the fulfillment of the statistical 
assumptions. If the requirement of the statistical assumptions is fulfilled Independent Sample T-Test is run.

The first statistical assumption required to fulfill is normality testing. It is to see whether the data distribution is normal. The calculation used is KolmogorovSmirnov Test. From the table 6 it is obvious that significance values obtained from control group and experimental group's writing scores are higher than .0 .5 -i.e. .303 and .985 respectively. This means that the data distribution is normal.

Table 4: One-Sample Kolmogorov-Smirnov Test

\begin{tabular}{|ll|r|r|}
\hline & & Control Group & $\begin{array}{c}\text { Experimental } \\
\text { Group }\end{array}$ \\
\hline N & & 25 & 22 \\
Normal Parameters & & 61.0000 & 60.3409 \\
& Mean & 7.68386 & 5.47589 \\
& Std. Deviation & .194 & .097 \\
& Absolute & .194 & .077 \\
& Positive & -.094 & -.097 \\
Kolmogorov-Smirnov $Z$ & Negative & .970 & .457 \\
Asymp. Sig. (2-tailed) & & .303 & .985 \\
\hline
\end{tabular}

a. Test distribution is Normal.

The second statistical assumption required to fulfil is homogeneity testing. It is to see whether the data variance is homogeneous. The calculation employed is Levene Test. Table 7 demonstrates that significance value is $.448>.05$. This means variance of the data is homogeneous.

Table 5: Test of Homogeneity of Variances of Writing Scores

\begin{tabular}{|r|r|r|c|}
\hline $\begin{array}{c}\text { Levene } \\
\text { Statistic }\end{array}$ & \multicolumn{1}{c|}{ df1 } & \multicolumn{1}{c|}{ df2 } & Siq. \\
\hline .587 & 1 & 45 & .448 \\
\hline
\end{tabular}

Hence, normality and homogeneity testing are fulfilled the data can be proceeded to analyze further using independent sample t-test. Table 8 indicates that significance value is higher that .0 .5 i.e. $.888>.0 .5$. Therefore, it can be concluded that students taught metacognitive strategy instruction do not achieve better scores in writing than those who are not. 
Table 6: independent sample t-test of writing scores

\begin{tabular}{|c|c|c|c|c|c|c|}
\hline \multicolumn{7}{|c|}{ Independent Samples Test } \\
\hline & & \multicolumn{2}{|c|}{$\begin{array}{c}\text { Levene's Test for Equality of } \\
\text { Variances }\end{array}$} & \multicolumn{3}{|c|}{ t-test for Equality of Means } \\
\hline & & $\mathrm{E}$ & $\mathrm{Sia}$ & t & $\mathrm{df}$ & Sig N-tailed) \\
\hline \multirow[t]{2}{*}{ Wuriting Test } & $\begin{array}{l}\text { Equal variances } \\
\text { assumed }\end{array}$ & .404 & .532 & -.146 & 20 & .886 \\
\hline & $\begin{array}{l}\text { Equal wariances not } \\
\text { assumed }\end{array}$ & & & -.143 & 17.749 & .888 \\
\hline
\end{tabular}

\begin{tabular}{|c|c|c|c|c|c|}
\hline \multicolumn{6}{|c|}{ Independent Samples Test } \\
\hline & & \multicolumn{4}{|c|}{ t-test for Equality of Means } \\
\hline & & \multirow[b]{2}{*}{$\begin{array}{l}\text { Mean } \\
\text { Difference }\end{array}$} & \multirow[b]{2}{*}{$\begin{array}{l}\text { Std. Eтror } \\
\text { Difference }\end{array}$} & \multicolumn{2}{|c|}{$\begin{array}{l}\text { 95\% Confidence Intenual of the } \\
\text { Difference }\end{array}$} \\
\hline & & & & Lower & Woner \\
\hline \multirow[t]{2}{*}{ Wuriting Test } & $\begin{array}{l}\text { Equal variances } \\
\text { assumed }\end{array}$ & -.35000 & 2.40126 & -5.35895 & 4.65895 \\
\hline & $\begin{array}{l}\text { Equal variances not } \\
\text { assumed }\end{array}$ & -.35000 & 2.43994 & -5.48132 & 4.78132 \\
\hline
\end{tabular}

Table 10 demonstrates that significance value is higher than .0 .5 i.e. $.888>.0 .5$. Thus, it can be revealed field-independent students and field-dependent students taught metacognitive strategy instruction have no significant differences in their writing scores.

Table 7: independent sample t-test of field-dependence and field-independence

\begin{tabular}{|c|c|c|c|c|c|}
\hline \multicolumn{6}{|c|}{ Group Statistics } \\
\hline & Learning Styles & $\mathrm{N}$ & Mean & Std. Deviation & $\begin{array}{l}\text { Std. Error } \\
\text { Mean }\end{array}$ \\
\hline Wiriting Test & Field-Independent & 10 & 60.1500 & 6.11033 & 1.93226 \\
\hline & Field-Dependent & 12 & 60.5000 & 5.16104 & 1.48986 \\
\hline
\end{tabular}

\begin{tabular}{|c|c|c|c|c|c|c|c|}
\hline & & \multicolumn{6}{|c|}{ Independent Samples Test } \\
\hline & & \multicolumn{2}{|c|}{$\begin{array}{c}\text { Levene's Test for Equality of } \\
\text { Variances }\end{array}$} & \multicolumn{4}{|r|}{ t-test for Equality } \\
\hline & & $\mathrm{F}$ & Siq. & $t$ & df & Siq. (2-tailed) & $\begin{array}{c}\text { Mean } \\
\text { Difference }\end{array}$ \\
\hline Writing Test & $\begin{array}{l}\text { Equal variances } \\
\text { assumed }\end{array}$ & \multirow[t]{2}{*}{.404} & \multirow[t]{2}{*}{.532} & -.146 & 20 & .886 & -.35000 \\
\hline & $\begin{array}{l}\text { Equal variances not } \\
\text { assumed }\end{array}$ & & & -.143 & 17.749 & .888 & -.35000 \\
\hline
\end{tabular}




\subsection{Discussion}

The calculation from independent sample t-test proves that both experimental group and control group have no significant differences in their writing scores in which this indicates that metacognitive strategy instruction gives no any influence toward the experimental group. This finding is contrast to the one discovered by several previous researchers such as Azizi et al (2017), Goctu (2017), Lv\& Chen, 2010, Nosratinia\&Adibifar (2014), and Xia (2017). All these researchers conclude that metacognitive strategy instruction significantly improves students' writing performance. There are several possible factors which cause the findings of this present study have contrary toward the aforementioned related studies. These possible factors might lie in the subjects' English proficiency level, the subjects' unfamiliarity on metacognitive learning strategies, length of time of the conducted treatment, and the way of metacognitive strategy instruction is presented.

Basic English proficiency level belonged to the subjects of this present study might make metacognitive strategy instruction they receive is not applied well. The subjects are not selected based on any particular English proficiency test. English proficiency level of these subjects is different from Azizi, et al (2017) and Nostratinia and Adibifar (2014)' one. The subjects' English proficiency levels of Azizi, et al (2017) are upper-mediate to advanced. Nostratinia and Adibifar (2014)' subjects are intermediate EFL learners. Additionally, in Nostratinia and Adibifar (2014)'s study, only those who can pass a language proficiency test namely the Cambridge Preliminary English Test (PET) are selected as the subjects.

Unfamiliarity on metacognitive learning strategy could be the next factor causing this strategy does not influence the subjects' writing skill. The subjects have never been introduced about this learning strategy before the treatment. Accordingly, they might lack of experience in applying this strategy for their writing process. They might still treat metacognitive learning strategy in introduction phase. On the contrary, the subjects in Azizi et al (2017), Goctu (2017), and Xia (2017)' studies have known and even employed metacognitive learning strategy in their learning processes before the treatment. The familiarity on metacognitive strategy might become one of factors which make this learning strategy improves their writing performance.

Length of time of conducting the treatment could determine success or failure of the treatment. This study conducts the treatment only for two months involving 
ten meetings. Amount of that period might not be sufficient for them to apply the metacognitive learning strategy into their writing process at maximum portion. On the other hand, Goctu (2017), Xia (2017), and Lv\& Chen (2010) implement the treatment for one semester, 15 weeks, and four months respectively.

The way of metacognitive strategy instruction is presented could affect effectiveness or ineffectiveness this strategic instruction to the subjects' writing performance. metacognitive strategy instruction in this present study is integrated with collaborative writing. In this case, every part of essay is outlined in group yet composing the essay is done individually. Every session in the writing process, as well as the writing feedback given by the lecturer and pair, are done using metacognitive strategy. There might be nothing wrong with collaborative writing as the approach. However, the subjects might rely much on collaborative writing so they do not really employ metacognitive strategy as the main guidance in their learning process of writing.

Metacognitive strategy instruction presented in this current study is different from the one in Azizi, et al (2017). In their study, before being lectured metacognitive learning strategy, the subjects are given questionnaire about metacognitive. This might lead them on realizing metacognitive strategy they have used either consciously or unconsciously. Goctu (2017) has different way before presenting metacognitive strategy instruction i.e. they make their subjects discuss and brainstorm about metacognitive strategy before they get explanation about what it is. In this current study, metacognitive strategy is directly presented without having them discuss. In Goctu (2017)'s study, the subjects are initially managed, directed, regulated and guided when having writing production. In this current study, such scaffolding is rarely applied.

Xia (2017) provides some ways of teaching metacognitive learning strategies different from the ones used in this current study. The ways Xia (2017) employs are the use of Cohen's (2000) models for strategy training, filling metacognitive questionnaire, and the implementation of zone of proximal development. The various ways used in Xia (2007)'s study which focus much on the metacognitive strategy itself make the learning strategy improves the subjects' writing skill.

In Nostratinia and Adibifar (2014), the subjects are given metacognitive training in some steps. One of them is they receive the instruction based on a particular book. 
The instruction is given in two phases. The first one is familiarizing the subjects with the principles of these strategies (Based on O'Mally and Chamot's Model, 1989). The second one is teaching them on how to use these strategies practically in their writing process (Based on Oxford's Model, 1990).

Lv \& Chen (2010) give instruction on metacognitive strategy by providing selfasking questions about individual writer' cognitive level and writing level; the comparison between self and other students' writings; and the factors which influence writing level and writing activities. The subjects' motivation is aroused by providing them with beautiful essays, good music, classic movies to shape their temperament and inspire their writing aspiration.

It is stated in the research finding that both field-independent and field-dependent learners have difference in their writing scores. This finding is quite different from the one of previous related study. In this case, the only study which correlates metacognitive learning strategy in writing to field-independent and field-dependent learning styles belongs to Nosratinia \& Adibifar (2014)'s. Their study demonstrates that field-independent learners' writing scores outperform field-dependent learners'.

\section{CONCLUSION AND SUGGESTION}

\subsection{Conclusion}

Objectives of undertaking this current study are to measure whether the students who receive metacognitive strategy instruction achieve higher scores in writing essay than those who do not receive the instruction and to identify whether fieldindependent students and field-dependent students have significant differences in their writing score after receiving metacognitive strategy instruction. Based on calculation using independent sample t-test on the first objective, significance value is higher that 0.5 i.e. $.888>.0 .5$. This means that students taught metacognitive strategy instruction do not achieve better scores in writing than those who are not. Meanwhile, calculation on the second objective using the same parametric test, it is discovered that significance value is higher that .0 .5 i.e. $.888>.0 .5$. This can be revealed field-independent students and field-dependent students taught metacognitive strategy instruction have no significant differences in their writing scores. 


\subsection{Suggestion}

The findings of this current study yield some suggestions for lecturer and prospective researchers. Before giving metacognitive strategy instruction in writing, the lecturer should ensure that her/his students have mastered the basic concepts on essay such as thesis statement, topic sentences and concluding remarks. It is because the components of metacognitive learning strategies -i.e. planning, monitoring, and evaluating -deal with those basic concepts. Moreover, the lecturer is responsible for making the students understand and apply the learning strategies properly. Accordingly, the lecturer needs to prepare the lesson plan very well, do scaffolding, and set classroom management well. If the lecturer integrates metacognitive strategy instruction with other teaching approach, she/he has to deliver both equally. [] 


\section{REFERENCES}

Aliyu, M M. 2016. Developing Undergraduates' Awareness of Metacognitive Knowledge in Writing Through Problem-based Learning. International Journal of Applied Linguistics \& English Literature. 5(7), 233-240.

An, X \& Shi, Z. 2013. Does Metacognitive Instruction Improve Listening Comprehension? Theory and Practice in Language Studies. 3(4), 632-636.

Azizi, Nemati, \& Estahbanati. 2017. Meta-Cognitive Awareness of Writing Strategy Use among Iranian EFL Learners and Its Impact on Their Writing Performance. International Journal of English Language \& Translation Studies. 5(1), 42-51.

Birjandi, P. 2012. The Effect of Metacognitive Strategy Instruction on the Listening Performance of EFL Students. International Journal of Linguistics. 4(2), 1948-5425.

Boghian, I. 2016. Metacognitive Learning Strategies in Teaching English as a Foreign Language. Journal of Innovation in Psychology, Education and Didactics. 20(1), 53-62.

Chamot, A U. 1998. Teaching Learning Strategies to Language Students. Center for Applied Linguistics, Washington, DC.

Chamot, A U. 2004. Issues in Language Learning Strategy Research and Teaching. Electronic Journal of Foreign Language Teaching. 1(1), 14-26

Creswell, J.W. 2012. Educational Research: Planning, Conducting, and Evaluating Quantitative and Qualitative Research (4 ${ }^{\text {th }}$ edn.). Boston: Pearson.

Farahian, M. 2015. Assessing EFL learners' writing metacognitive awareness. Journal of Language and Linguistic Studies, 11(2), 39-51

Farahian, M. 2017. Developing and validating a metacognitive writing questionnaire for EFL learners. Issues in Educational Research. 27(4), 736-750

Goctu, R. 2017. Metacognitive Strategies in Academic Writing. Journal of Education in Black Sea Region. 2(2), 82-96. 
Han, J. 2014. A study on the influence of anxiety and metacognitive strategies on listening proficiency. Journal of Chemical and Pharmaceutical Research. 6(6), 2484-2496.

Jayanti, F G. 2014. The Effects of Integrated Reading-Writing Instruction on Students' Writing Ability across Students' Cognitive Styles. Unpublished Thesis. State University of Malang.

Khaki, Nasrin, Hessamy \& Gholamreza. 2013. Metacognitive Strategies Employed by EFL Writers in Integrated and Independent Writing Tasks. World Applied Sciences Journal 22(11), 1586-1593.

Khulel, B. 2017. Implementing Metacognitive Strategy Instruction to Improve Listening Comprehension Skill of Undergraduate Students of English. Graduate Study in English Language Teaching. Universitas Negeri Malang

Kirszner, L G. and Mandell S R. 2009. Writing First with Reading Practice in Context. New York: Bedfort.

Latief, M A. 2012. Research Methods on Language Learning An Intoduction. Malang: UM Press.

Lu, W. 2015. Metacognitive reading strategies of esl learners with different field independent/field dependent cognitive styles. Faculty of languages and linguistics university of Malaya: Kuala Lumpur

Lv, F \& Chen, H. 2010. A Study of Metacognitive-Strategies-Based Writing Instruction for Vocational College Students. English Language Teaching. 3(3), 136-144.

Mekala, Shabitha, \& Ponmani. 2016. The Role of Metacognitive Strategies in Second Language Writing. GSTF Journal on Education (JEd). 4(1), 11-19.

Nejad, S P. 2015. The effect of metacognitive strategy instruction on listening performance pre-intermediate iranian efl learners. Indian Journal of Fundamental and Applied Life Sciences. 5(3), 1474-1480. 
Nosratinia, M \& Adibifar, S. 2014. The Effect of Teaching Metacognitive Strategies on Fielddependent and Independent Learners' Writing. Procedia-Social and Behavioral Sciences. 9(8), 1390-1399.

Nozari, A Y \& Siamian, H. 2015. The Relationship between Field DependentIndependent Cognitive Style and Understanding of English Text Reading and Academic Success. Mater Sociomed. 27(1), 39-41.

Ningrum, A S B. 2013. The Effects of Mind Mapping on Argumentative Writing of Students of Different Gender with Different Learning Styles. Unpublished Thesis. State University of Malang

Pariyanto. 2017. The Effect of Corrective Feedback on Grammatical Accuracy in the Writing of EFL University Students. State University of Malang. Unpublished Dissertation.

Rahimi, M. \& Katal, M. 2013. The Impact of Metacognitive Instruction on EFL Learners' Listening Comprehension and Oral Language Proficiency. The Journal of Teaching Language Skills (JTLS). 5(2), 69-90.

Rezaee, M \& Farahian, M. 2012. The case study of a field-independent English language learner. Procedia-Social and Behavioral Sciences. 47, 114 - 119

Riddel, J. 2015. Performance, Feedback, and Revision: Metacognitive Approaches to Undergraduate Essay Writing. Collected Essay on Learning and Teaching. 8, 79-96

Saadatmanesh, S. 2013. Field Dependent/Independent Learning Strategies and the Knowledge of the Musical Notes. Journal of Science and today's world. 2(9), 1204-1210.

Salkind, N. J. 2000. Statistics for People Who Hate Statistics. USA: Sage Publications, Inc.

Sulistyo, G. H. 2018. Assessment at Schools: An Introduction to Its Basic Concepts and Principles. Malang: CV Bintang Sejahtera.

Tyas, P A, 2012, The Effectiveness of Providing Students with a Scoring Guide in Teaching Writing. State University of Malang: Unpublished Thesis. 
Weigle, S C. 2009. Assessing Writing: Cambridge Language Assessment Series. United Kingdom: Cambridge University Press.

Xia, T. 2017. Application of Metacognitive Strategies in EFL Writing Instruction. Advances in Social Science, Education and Humanities Research. 142, 159165

Yang, C. 2009. A Study of Metacognitive Strategies Employed by English Listeners in an EFL Setting. International Education Studies. 2(4), 134-39.

Zare, P. 2012. Language Learning Strategies Among EFL/ESL Learners: A Review of Literature. International Journal of Humanities and Social Science. 2(5), 162-169.

Zarrabi, F. 2016. The Impact of Listening StrategyTraining on the Meta-Cognitive Listening Strategies Awareness of Different Learner Types. English Language Teaching. 9(5), 154-165 